\title{
Dune vegetation and coastal thicket plant communities in threatened limestone fynbos of Andrew's Field and Tsaba-Tsaba Nature Reserve, Struisbaai, Western Cape
}

\section{M.M. ZIETSMAN and G.J. BREDENKAMP}

\begin{abstract}
Zietsman, M.M. and G.J. Bredenkamp. 2006. Dune vegetation and coastal thicket plant communities in threatened Limestone Fynbos of Andrew's Field and Tsaba-Tsaba Nature Reserve, Struisbaai, Western Cape. Koedoe 49(1): 33-47. Pretoria. ISSN 00756458.

The coastal thicket and dune vegetation of Andrew's Field and Tsaba-Tsaba Nature Reserve was classified using Braun-Blanquet procedures and TWINSPAN. The vegetation was sampled using 74 randomly stratified sample plots. The floristic composition, cover-abundance of each species, and several environmental variables were recorded in each sample plot. Six plant communities were identified, namely, Rhus glauca - Euclea racemosa low to tall closed thicket community; Chrysanthemoides monilifera Solanum africanum low closed dune shrub community; Chrysanthemoides monilifera Ehrharta villosa var. maxima low to high closed dune shrub community; Ehrharta villosa var. maxima low to short closed dune grassland community; Ammophila arenaria low to short closed dune grassland community; and Arcthotheca populifolia - Thinopyrum distichum low to short open beach community. These were subdivided into eight subcommunities and four variants. All communities, sub-communities and variants were described and ecologically interpreted. The distribution of the communities, sub-communities and variants can mainly be ascribed to differences in landform, rockiness of the soil surface the degree of protection / exposure of the vegetation to the dominating winds of the area.
\end{abstract}

Key words: coastal thicket, conservation area, endemic plants, Limestone Fynbos, phytosociology, plant communities, TWINSPAN, Western Cape

M.M. Zietsman and G.J. Bredenkamp, African Vegetation and Plant Diversity Research Centre, Department of Botany, University of Pretoria, Pretoria, 0002 Republic of South Africa.

\section{Introduction}

A sound knowledge of the ecology of the area is an essential prerequisite for the establishment of efficient wildlife management programmes and compilation of conservation policies for any area (Edwards 1972). Vegetation science has been applied in the fields of nature conservation for years, but recent developments relate to the application of plant ecological knowledge to environmental management (Scheepers 1983). Bredenkamp \& Brown (2001) emphasise the use of plant communities as a reliable basis for any ecological planning and management.

To obtain knowledge of the ecology of the study area, a study of the vegetation of the area should be made at the plant community level of organisation (Bredenkamp \& Brown 2001). Studying the vegetation of an area allows the identification, description and classification of plant communities. On the basis of the plant communities as vegetation units, management units can be delineated. Vegetation studies also allow the identification of ecologically sensitive areas, bush encroached areas or areas infested with alien plants, degraded areas, habitats of rare or endangered plant species, and habitats of specific animals.

The Andrew's Field and Tsaba-Tsaba Reserve is situated in the Bredasdorp/Riversdale Centre of Endemism (Cowling 1992). This centre of endemism refers to a welldefined group of plants, confined to the lime- 
stone of the Bredasdorp Formation and associated colluvial deposits (Heydenrych 1994). According to Hilton-Taylor \& Le Roux (1989) Limestone Fynbos is one of the most threatened vegetation types in the Cape Floristic Region. Factors threatening Limestone Fynbos vegetation include alien plants (considered the biggest problem), land clearing, resort development, inappropriate fire management and over-harvesting of flowers (Heydenrych 1994).

Thicket encroachment into the adjacent Limestone Fynbos and Renosterveld is therefore a serious threat to the species-rich Fynbos with many endemic and red data species. The species richness of coastal thicket in the reserve is very low compared to those of the adjacent Limestone Fynbos and Renosterveld communities (Zietsman \& Bredenkamp in press) and the true thicket species like Rhus glauca and Euclea racemosa are neither rare nor endemic. Regarding the importance of the conservation of Limestone Fynbos in areas where the thicket communities occur, the effective management of the area becomes all the more important, and fully justifies a detailed vegetation study of the coastal thicket.

\section{Study area}

The reserve is situated in the Bredasdorp district, Western Cape, between Struisbaai North in the south and De Mond State Forest in the north. It is bordered in the west by the Bredasdorp/Struisbaai road, and in the south by the coastline. The study area is situated close to the coastal town of Struisbaai. The Andrew's Field (129 ha) and Tsaba-Tsaba Nature Reserve is approximately 979 ha in extent. Approximately one third of the study area consists of the coastal vegetation, which is dealt with in this report. The remainder of the study area consists of inland plains and hills, described by Zietsman \& Bredenkamp (in press).

The dominant substrate in the study area is the Bredasdorp Group (Malan et al. 1994). Two formations of the Bredasdorp Group namely Strandveld and Waenhuiskrans formations are found in the study area (Malan et al. 1994). Beach and terrace deposits, not formally named as a formation, but forming part of the Bredasdorp Group, are found in the form of roll-stones on the coastal beach (Malan et al. 1994). Previous changes in sea level resulted in the presence of roll-stones of Table Mountain Sandstone.

The Strandveld Formation is restricted to the coast. It consists of white to light-grey dune sands with a high percentage shell fragments. Partial cementing of sands is a result of the high calcium carbonate content in the sand. The lithology of this formation is described as white dune sand, strand sand with finely divided shell and alluvial stones (Malan et al. 1994).

The Waenhuiskrans Formation forms outcrops adjacent to the current coastline. The Waenhuiskrans stratiotype is $12.4 \mathrm{~m}$ deep, is locally overlain with $1 \mathrm{~m}$ thick calcretes and consists of medium-grained cross-layered calcarenite with well-rounded quartz and a few glauconite grains. Large-scale aeolic cross-layers are characteristic of the unit. The lithology of this formation is described as partially calcified dune sand (Malan et al. 1994).

The study area is situated on the Agulhas Plain, a coastal lowland. The majority of the area falls below the $10 \mathrm{~m}$ contour (Jefferey 1996). Coastal dunes and dune plains are typical in this area, with the highest point on a ridge $31 \mathrm{~m}$ above sea level.

The soil can be described as shallow sandy soil, overlying limestone, or shallow to deep sandy soil, overlying clay, silt and gravel. Four different soil forms have been distinguished in the area (MacVicar 1991):

- Coega: Orthic A on hard bank carbonate horizon; family Marydale: lime containing A-horizon. This soil form is found on the limestone hills and shallow-soil limestone plain.

- Immerpan: Melanic A on hard bank carbonate horizon; family Kalkpan: lime containing A-horizon. This soil form is found on the proteoid dominated limestone plain 


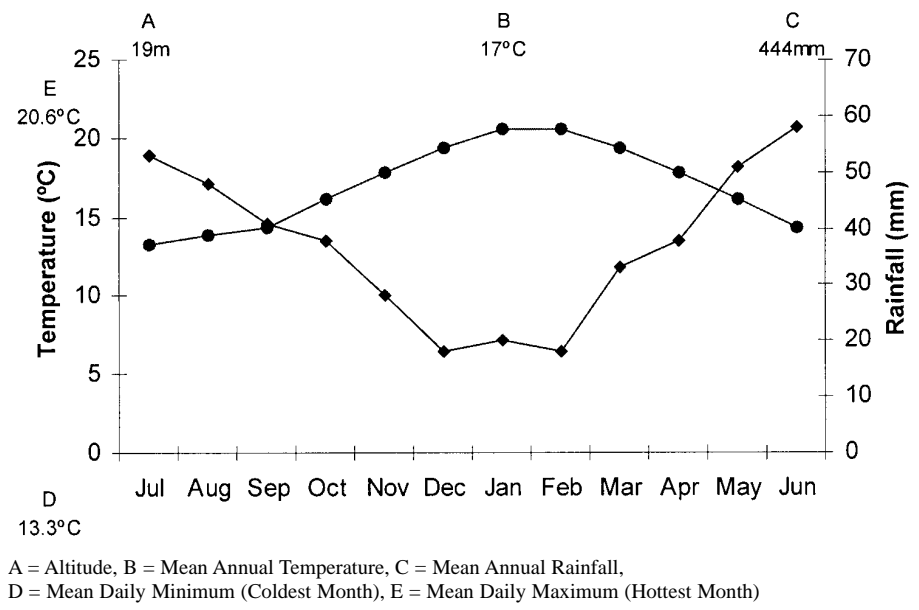

Fig. 1. A Walter climatic diagram for Andrew’s Field and Tsaba-Tsaba Nature Reserve.

where the soil is deep.

- Brandvlei: Orthic A on soft carbonate horizon; family Kolke: signs of wetness in carbonate horizon. The marsh area is characterised by this soil form.

- Namib: Orthic A on regic sand; family Beachwood: containing lime within 1500 $\mathrm{mm}$ from soil surface. This soil form is found on the dune plain and the deep-sand plains.

According to Tinley (1985) two distinct sand characteristics occur in dune fields. Bare dune sands, yellow in colour, absorbs all rain and consequently there is no surface runoff. Grey sands, stained by humus and covered with woody vegetation, have a water repellent layer near the surface, beneath the litter, causing a massive surface runoff when heavy rains follow a dry period (Tinley 1985).

The main factors affecting the climate are the contrasting sea surface temperatures of the two major ocean currents and the inshore circulation (Tinley 1985). According to the geographical division of Heydorn \& Tinley (1980), the reserve is situated on the south coast, which is a transitional zone between tropical and temperate waters.
The study area is situated in the transitional zone between the winter-rainfall region in the west and the non-seasonal rainfall region in the east (Mustart et al. 1997). The south coast has a warm temperate climate with allseasons and bimodal equinoctial rainfall (Strydom 1992). The average annual precipitation of the area is $444 \mathrm{~mm}$. Precipitation is mostly rain, but it also occurs in the form of fog. The maximum precipitation is in June, and the minimum during February and December. According to Heydorn \& Tinley (1980) the study area is situated in a low rainfall region, within an arid belt protruding into the interior from the coast. The low rainfall appears to be the result of cold inshore waters that inhibit shoreline rains. A Walter climatic diagram was compiled (Fig. 1) from data obtained from the Agulhas weather station.

The average annual maximum and minimum temperatures for the area are $6^{\circ} \mathrm{C}$ and $13.3^{\circ} \mathrm{C}$ respectively. The maximum temperature for the area was $36.1^{\circ} \mathrm{C}$, obtained in February. The minimum temperature for the area is $3.9^{\circ} \mathrm{C}$, obtained in June (Zietsman \& Bredenkamp in press).

The wind along the south coast is bidirectional. Southeasterly winds alternate with 
northwesterly and southwesterly winds (Heydorn \& Tinley 1980).

\section{Methods}

Relevés were compiled in 74 stratified sample plots, placed in relatively homogeneous areas, representative of particular plant communities that occur in a mosaic distribution pattern. A plot size of $10 \mathrm{~m}^{2}$ was used, and considered as large enough to ensure that all species of regular occurrence in the stand are present in the sample plot. Sample plots were placed in such a way as to ensure that each plot adequately represents the structure of the particular vegetation (Werger 1974). A list of plant species found in each sample plot was compiled. The cover-abundance of each species in the sample plot was assessed, using the Braun-Blanquet cover-abundance scale (Werger 1974). Cover of the height classes of the different strata (Edwards 1983) was estimated and the vegetation was structurally classified according to the Edwards (1983) structural classification system. The following habitat characteristics were recorded in each sample plot: altitude, topographical position, exposure to wind (seaward or towards the land), slope angle, slope direction, geology, soil, percentage rock cover and biotic influence. Six main different habitat types are found in the study area, namely dune plain, Renosterveld plain, limestone plain, limestone hills, dunes and beach. These were recorded in each sample plot.

To obtain a first approximation of the plant communities of the area, relevés were classified using TWINSPAN (Hill 1979), and these results were then refined by application of the classical BraunBlanquet methodology (Behr \& Bredenkamp 1988).

\section{Results}

\section{Classification}

The results obtained from the classification are presented in a phytosociological table (Table 1). In naming the plant communities, diagnostic and/or dominant species were used in combination with the Edwards (1983) structural classification.

1. Rhus glauca - Euclea racemosa Low to Tall Closed Thicket Community

1.1 Rhus lucida - Euclea racemosa Low to Short Closed Thicket Sub-community

1.2 Pterocelastrus tricuspidatus - Euclea racemosa Short to Tall Closed Thicket
Sub-community

1.2.1 Olea exasperata - Euclea racemosa Short to High Closed Thicket Variant

1.2.2 Carissa bispinosa - Euclea racemosa short to Tall Closed Thicket Variant

1.3 Acmadenia obtusata - Euclea racemosa Short to Tall Closed Thicket Subcommunity

1.4 Helichrysum dasyanthum - Euclea racemosa Low to Short Closed Thicket Sub-community

1.5 Acacia cyclops - Euclea racemosa High to Tall Closed Thicket Sub-community

1.6 Thamnocortus insignis - Euclea racemosa High to Tall Closed Thicket Subcommunity

1.6.1 Elytropappus rhinocerotus Euclea racemosa Short to Tall Closed Thicket Variant

1.6.2 Leucadendron coniferum - Euclea racemosa High to Tall Closed Thicket Variant

2. Chrysanthemoides monilifera - Solanum africanum Low Closed Dune Shrub Community

3. Chrysanthemoides monilifera - Ehrharta villosa var. maxima Low to High Closed Dune Shrub Community

3.1 Chrysanthemoides monilifera - Rhus crenata Short to High Dune Shrub Subcommunity

3.2 Chrysanthemoides monilifera - Morella cordifolia Low to Short Closed Shrub Sub-community

4. Ehrharta villosa var. maxima Low to Short Closed Dune Grassland Community

5. Ammophila arenaria Low to Short Closed Dune Grassland Community

6. Arcthotheca populifolia - Thinopyrum distichum Low to Short Open Beach Community

The cover and height of various strata of the main plant communities are given in Table 2 . The hierarchical classification and associated environmental interpretation of the plant communities is given in Fig. 2. The community numbers in Fig. 2 correspond with the plant community numbers used in the descriptions in the text.

1. Rhus glauca - Euclea racemosa Low to Tall Closed Thicket Community

The community is found close to the sea on the dune plains, limestone plains, Renoster- 


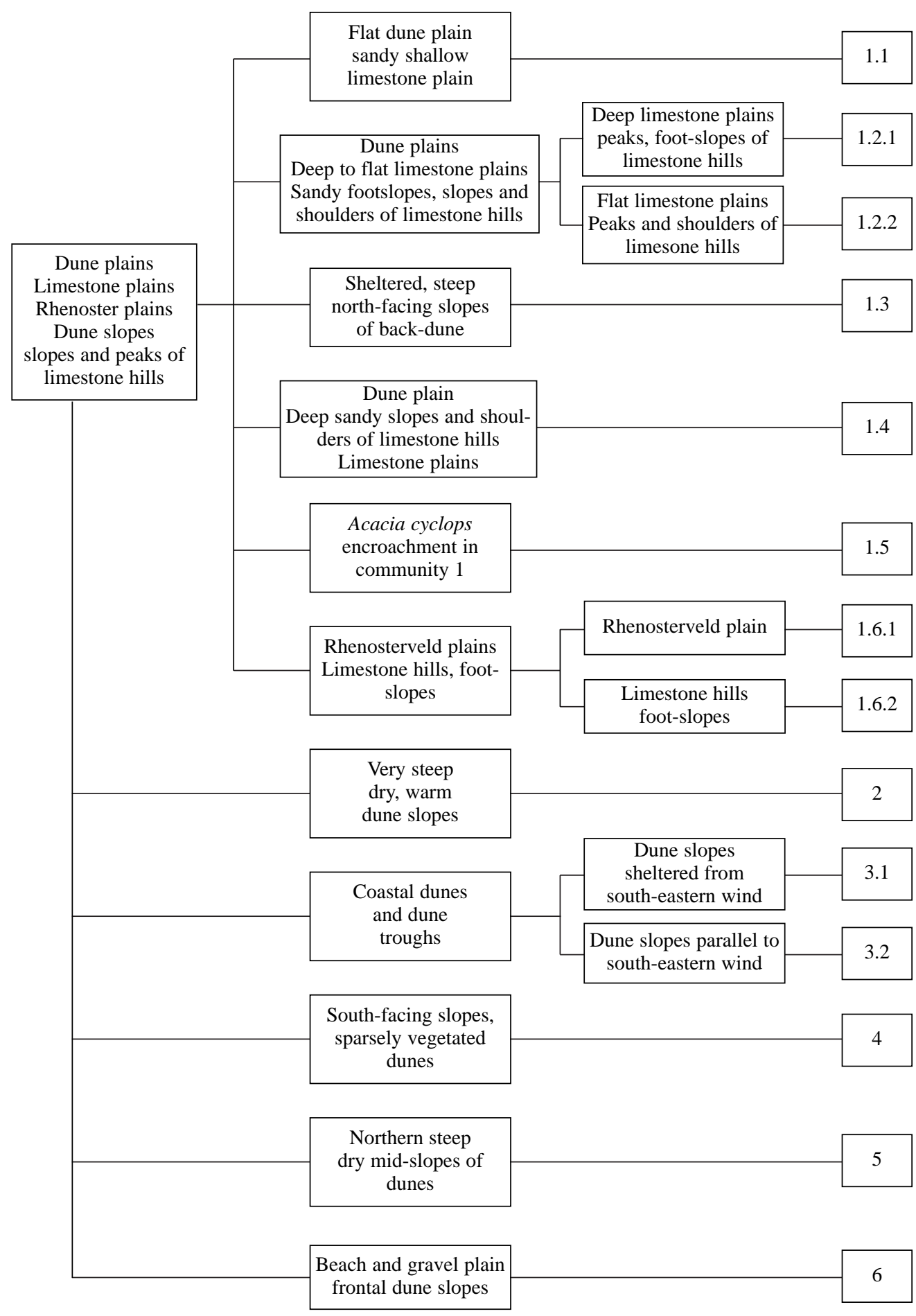

Fig. 2. Hierarchical classification and associated environmental characteristics of the coastal thicket, dunes and strand of Andrew's Field and Tsaba-Tsaba Nature Reserve. 


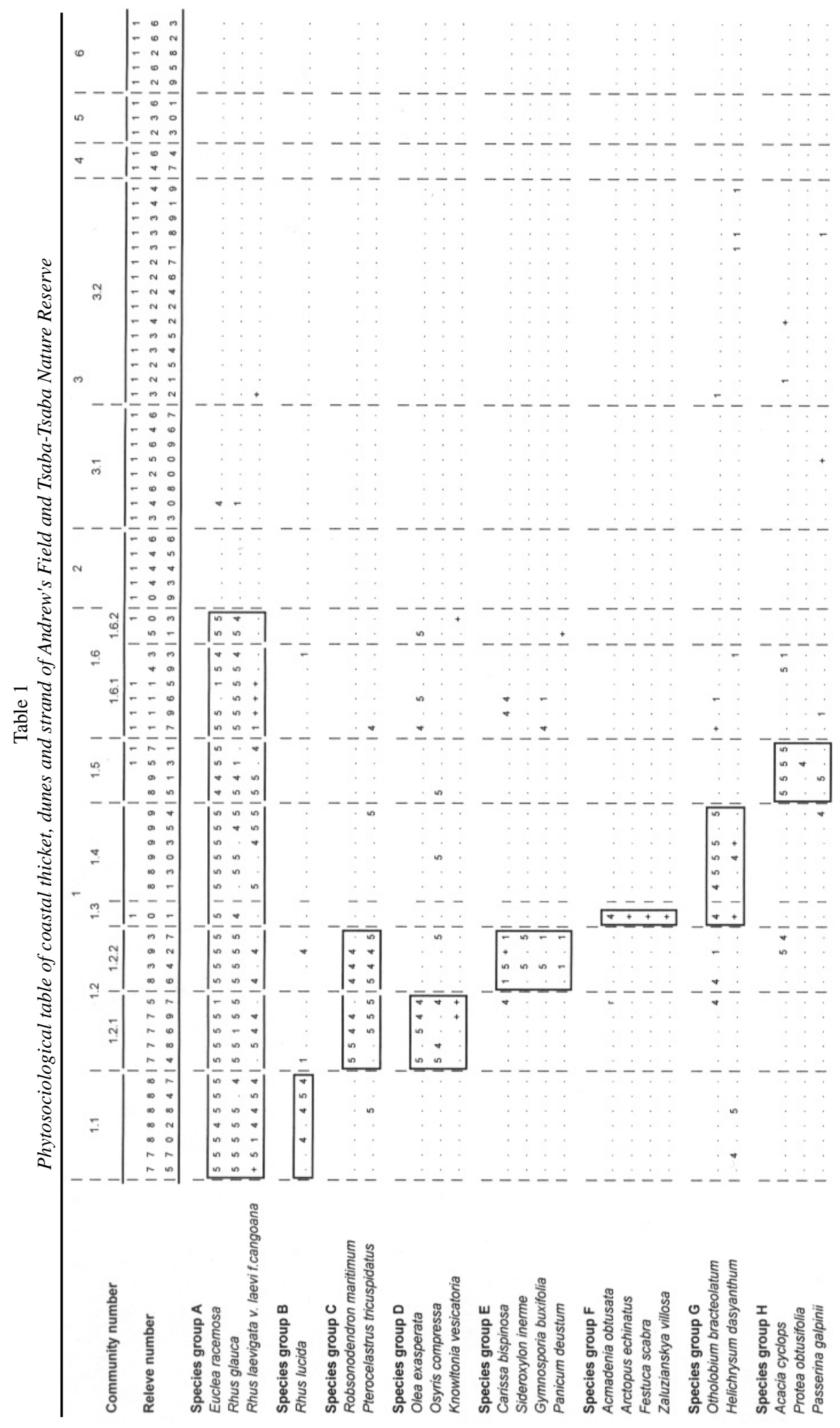




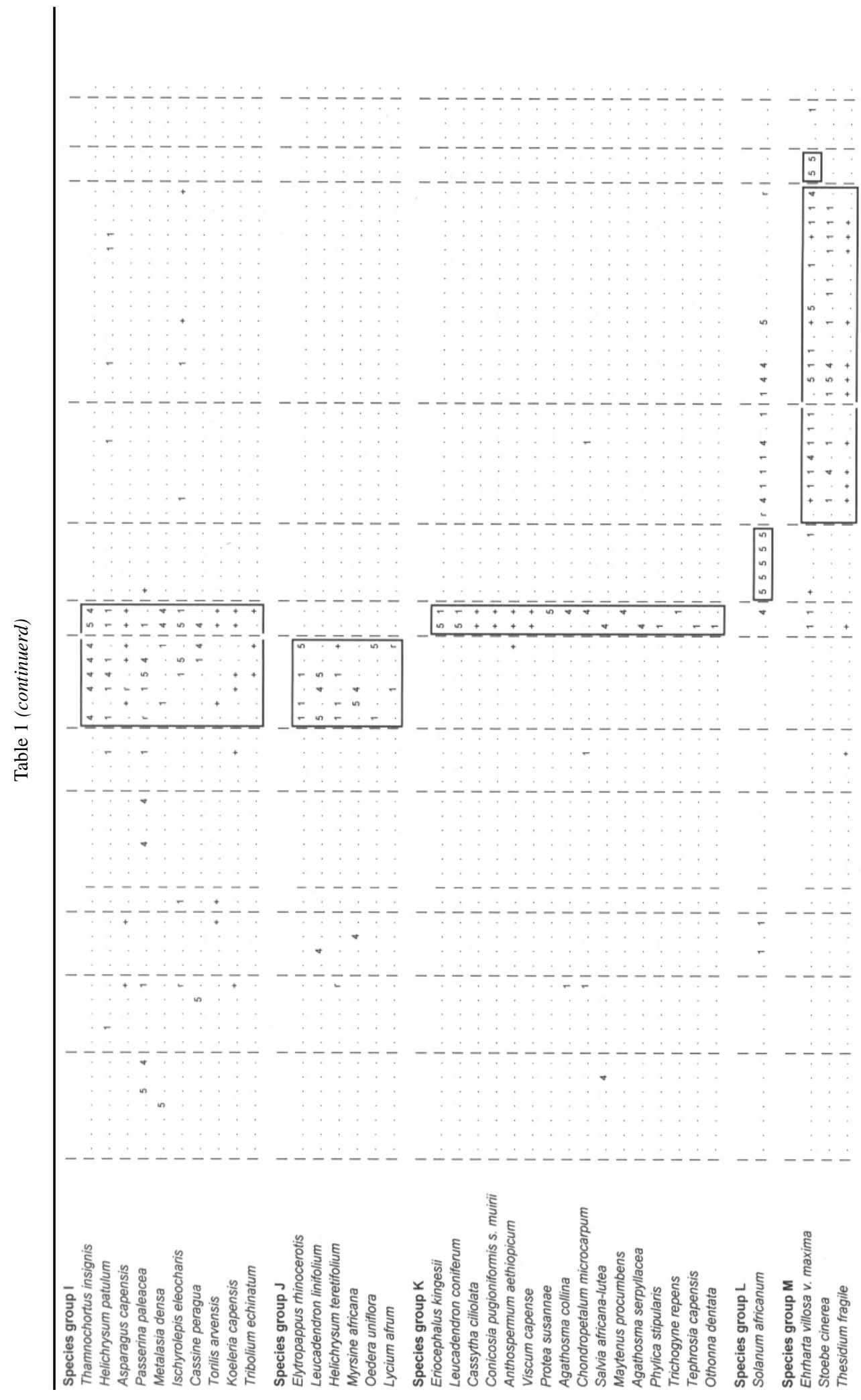




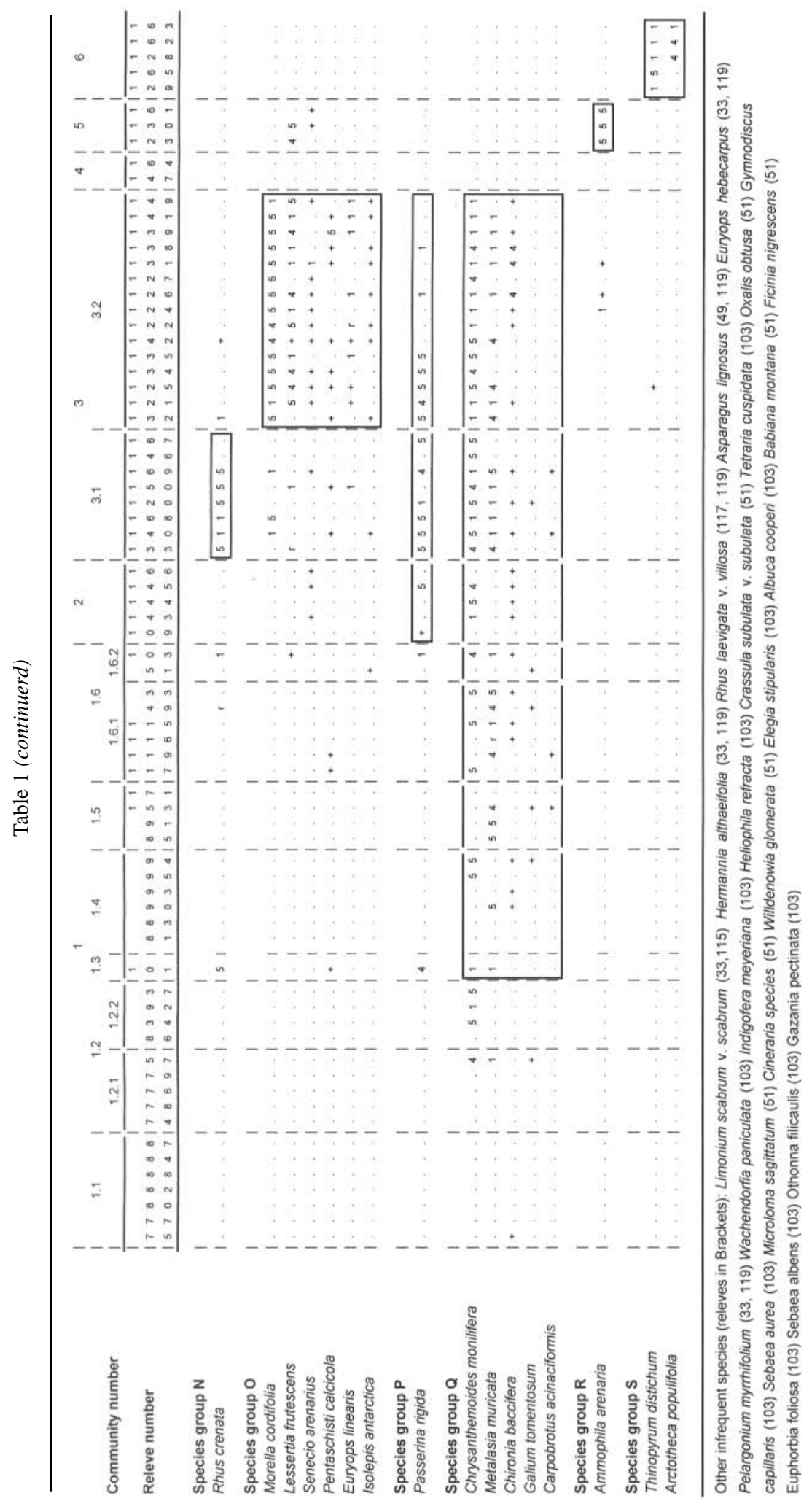


veld plains, northern slope of back-dunes, and on the slopes and peaks of limestone hills. These areas have a low cover of small irregular white-grey limestone pebbles.

The Rhus glauca - Euclea racemosa short to tall closed thicket community consists of scattered, dense groups of broad-leaved shrubs. These groups have high shrubs near the centre and lower shrubs near the periphery. The structure of the vegetation is given in Table 2. The shrub layer is most prominent, while restioid and grass layers cover $10 \%$ or less. Forbs and sedges have a very low cover.

The shrubs Euclea racemosa, Rhus glauca and Rhus laevigata (Species Group A, Table 1) are diagnostic and dominant in this community. Chrysanthemoides monilifera and Metalasia muricata (Species Group Q) are also prominent in the community.

In the absence of fire, these thickets tend to encroach into adjacent threatened Limestone Fynbos and Rhenosterveld communities which have several endemic and Red Data species (Cowling \& Richardson 1995; Heydenrych 1994; Zietsman \& Bredenkamp in press).

Six sub-communities, two of which have two variants, were identified:
1.1 Rhus lucida - Euclea racemosa Low to Short Closed Thicket Sub-community

This sub-community is found on the flat to undulating dune plain, Namib soil form and limestone plain, Brandvlei and Coega soil forms (Fig. 2). The vegetation forms scattered groups of low to short broad-leaved shrubs.

Rhus lucida (Species Group B, Table 1) is the only diagnostic species for this sub-community. The shrubs Euclea racemosa, Rhus glauca and Rhus laevigata var. laevigata for. coangoa (Species Group A, Table 1) are the dominants in this sub-community. The shrubby Helichrysum dasyanthum (Species Group G) and Passerina paleacea (Species Group I) are locally prominent in the subcommunity.

An average of only four species per relevé was recorded in this sub-community.

\subsection{Pterocelastrus tricuspidatus - Euclea racemosa Short to Tall Closed Thicket Sub-community}

The sub-community is found on the Namib soil form on the dune plain and on the Immerpan and Coega soil forms on sandy foot-slopes and shoulders of limestone hills (Fig. 2).

Table 2

Percentage Cover $(C)(\%)$ and Height $(H)(m)$ of the strata of the main plant communities

\begin{tabular}{|c|c|c|c|c|c|c|c|c|c|c|c|c|}
\hline \multirow{2}{*}{$\begin{array}{l}\text { Community } \\
\text { Stratum }\end{array}$} & \multicolumn{2}{|c|}{1} & \multicolumn{2}{|c|}{2} & \multicolumn{2}{|c|}{3} & \multicolumn{2}{|c|}{4} & \multicolumn{2}{|c|}{5} & \multicolumn{2}{|c|}{6} \\
\hline & $\mathrm{C}$ & $\mathrm{H}$ & $\mathrm{C}$ & $\mathrm{H}$ & $\mathrm{C}$ & $\mathrm{H}$ & $\mathrm{C}$ & $\mathrm{H}$ & $\mathrm{C}$ & $\mathrm{H}$ & $\mathrm{C}$ & $\mathrm{H}$ \\
\hline Tall shrub & 14 & 2.5 & 6 & 2.5 & 6 & 2.5 & - & - & - & - & - & - \\
\hline High shrub & 20 & 1.5 & 5 & 1.5 & 10 & 1.5 & - & - & 10 & 1 & - & - \\
\hline Short shrub & 28 & 0.75 & 5 & 0.75 & 29 & 0.75 & - & - & - & - & & \\
\hline Low shrub & 15 & 0.4 & 51 & 0.15 & 16 & 0.3 & - & - & - & - & & \\
\hline Forb & 3 & 0.3 & 1 & 0.3 & 2 & 0.3 & - & - & - & - & 10 & 0.5 \\
\hline Short restoid & 4 & 0.75 & - & - & 0.3 & 0.2 & - & - & - & - & & \\
\hline Low restoid & 7.5 & 0.4 & - & - & - & - & - & - & - & - & & \\
\hline Sedge & 1 & 0.15 & - & - & 0.5 & 0.15 & - & - & - & - & & \\
\hline High grass & - & - & - & - & 0.5 & 1.5 & 3.5 & 1.5 & - & - & & \\
\hline Short grass & 0.5 & 0.5 & 0.6 & 0.75 & 2 & 0.75 & 25 & 0.75 & 44 & 0.7 & 5 & 0.5 \\
\hline Low grass & 10 & 0.3 & - & - & 2 & 0.3 & 15 & 0.3 & - & - & 2 & 0.3 \\
\hline
\end{tabular}


The vegetation forms scattered groups of short to tall broad-leaved shrubs, with some lower shrubs at the periphery.

Species Group C (Table 1) is diagnostic for this sub-community, with the shrubby trees Robsonodendron maritimum and Pterocelastrus tricuspidatus dominant diagnostic species. The shrubs Euclea racemosa, Rhus glauca and Rhus laevigata var. laevigata for. coangoa (Species Group A), are also very prominent in the sub-community.

\subsubsection{Olea exasperata - Euclea racemosa} Short to High Closed Thicket Variant

The variant occurs on the slopes and peaks of the limestone hills, and on the sandy, deep-soil limestone plains (Fig. 2).

Species Group D (Table 1) is diagnostic, with Olea exasperata and Osyris compressa prominent diagnostic species.

The diagnostic species of the community and sub-community, namely the shrubs Euclea racemosa, Rhus glauca and Rhus laevigata var. laevigata for. coangoa (Species Group A), Robsonodendron maritimum and Pterocelastrus tricuspidatus (Species Group C) are dominant in the variant.

An average of 12 species per relevé was recorded for this variant.

\subsubsection{Carissa bispinosa Short to Tall Closed Thicket Variant}

This variant is restricted to the flat limestone plains and the shoulders and peaks of limestone hills (Fig. 2). This soil is of the Immerpan and Coega forms.

Species Group E (Table 1) is diagnostic with the shrubs Carissa bispinosa and Sideroxylon inerme the most prominent diagnostic species. The shrubs Euclea racemosa, Rhus glauca (Species Group A), Robsonodendron maritimum and Pterocelastrus tricuspidatus (Species Group C) are dominant whereas the alien shrub Acacia cyclops (Species Group H) is also locally prominent.
An average of 13 species per relevé was recorded for this variant.

\subsection{Acmadenia obtusata - Euclea racemosa Short to Tall Closed Thicket Sub-community}

The sub-community is restricted to a small patch close to the sea, in the central part of the reserve, on a steep $\left(26^{\circ}\right.$ to $\left.45^{\circ}\right)$, sheltered northern slope of a back-dune. The soil is of the Namib form and no rocks are found here. Only a single relevé represents this sub-community.

The vegetation forms scattered groups of short to tall closed broad-leaved shrubs, with some lower shrubs at the periphery.

Species Group F (Table 1) is diagnostic, with the shrub Acmadenia obtusata, the forbs Arctopus echinatus and Zaluzianskya villosa and the grass Festuca scabra, as diagnostic species. The shrubs Euclea racemosa (Species Group A), Otholobium bracteolatum (Species Group G), Rhus crenata (Species Group N) and Passerina rigida (Species Group P) are dominant.

Eighteen species were recoded in the single releve.

1.4 Helichrysum dasyanthum - Euclea racemosa Low to Short Closed Thicket Sub-community

This sub-community is widespread on the dune plain, Namib soil form, the sandy shallow-soil limestone plain and sandy slopes of limestone hills, Immerpan and Coega soil forms (Fig. 2).

The vegetation forms scattered groups of low to short broad-leaved shrubs, with some high shrubs at the centre.

Otholobium bracteolatum and Helichrysum dasyanthum (Species Group G, Table 1) are the diagnostic species for this sub-community. The shrubs Euclea racemosa, and Rhus laevigata var. laevigata for. coangoa (Species Group A) are dominant, while Rhus glauca (Species Group A), Pterocelastrus tricuspidatus (Species Group C), Passerina paleacea (Species Group I), Chrysanthe- 
moides monilifera (Species Group Q) are also locally prominent.

The sub-community contains an average of only six species per relevé.

\subsection{Acacia cyclops - Euclea racemosa High to Tall Closed Thicket Sub-community}

Locally the alien Acacia cyclops encroached into the Rhus glauca - Euclea racemosa short to tall closed thicket community.

Acacia cyclops, the shrubby tree Protea obtusifolia, and the shrub Passerina galpinii are the diagostic species for this sub-community (Species Group H, Table 1). Acacia cyclops and the shrubs Euclea racemosa, Rhus glauca and Rhus laevigata var. laevigata for. coangoa (Species Group A), and Metalasia muricata (Species Group Q) are dominant in the sub-community.

The sub-community contains an average of seven species per relevé.

1.6 Thamnochortus insignis - Euclea racemosa High toTall Closed Thicket Sub-community

The sub-community is found on the Renosterveld plain, Brandvlei soil form and on sandy foot-slopes of limestone hills, Namib soil form (Fig. 2).

The vegetation forms scattered groups of high to tall broad-leaved shrubs, with some low and short shrubs at the periphery. Low forbs and some high, low and short restioids are also present in the sub-community.

Species Group I (Table 1) is diagnostic for this sub-community with the restioid Thamnochortus insignis and the shrubs Helichrysum patulum, Passerina paleacea, Metalasia densa the most prominent diagnostic species. The shrubs Euclea racemosa, Rhus glauca (Species Group A), Chrysanthemoides monilifera and Metalasia muricata (Species Group Q), are also prominent in the subcommunity.

Two variants are recognised within this subcommunity:
1.6.1 Elytropappus rhinocerotus Short to Tall Closed Thicket Variant

The variant is found at an altitude of $3 \mathrm{~m}$ on the Renosterveld plain, Brandvlei soil form (Fig. 2).

The vegetation scattered groups of short to tall broad-leaved shrubs, with some lower shrubs at the periphery, as well as some high restioids.

The diagnostic species are listed in Species Group K (Table 1), which includes the shrubs Elytropappus rhinocerotis, Leucadendron linifolium, Oedera uniflora, Lycium afrum, Rhus laevigata var. villosa, Asparagus lignosus, Euryops hebecarpus, and the forbs Limonium scabrum var. scabrum, Hermannia althaeifolia and Pelargonium myrrhifolium. The shrubs Euclea racemosa and Rhus glauca (Species Group A) and the restioid Thamnochortus insignis (Species Group I) are dominant whereas the shrubs Helichrysum patulum, Passerina paleacea (Species Group I), Chrysanthemoides monilifer and Metalasia muricata (Species Group Q) are locally prominent.

The variant has an average of 22 species per relevé.

\subsubsection{Leucadendron coniferum High to Tall Closed Thicket Variant}

The variant is found on the sandy foot-slopes of limestone hills, Namib soil form (Fig. 2).

The vegetation forms scattered groups of high to tall closed broad-leaved shrubs, with some low to short shrubs at the periphery, as well as some high and low restioids.

A large number of species given in Species Group K (Table 1) are diagnostic for this variant, the most prominent being the shrubs Eriocephalus kingesii, Leucadendron coniferum, Protea susannae, Maytenus procumbens, Agathosma serpyllacea, Agathosma collina, Phylica stipularis, Trigogyne repens and Tephrosia capensis and the restioid Chondopetalum microcarpum. The shrubs Euclea racemosa and Rhus glauca (Species Group A), and the restioid Thamnochortus 
insignis (Species Group I) are dominant, while the shrubs Olea exasperata (Species Group D), Cassine peragua (Species Group I), Solanum africanum (Species Group L), Chrysanthemoides monilifera (Species Group Q) are locally prominent.

The variant is rich in species and has an average of 43 species per relevé.

\section{Chrysanthemoides monilifera - Solanum africanum Low Closed Shrub Dune Community}

The sparsely vegetated community is found in the shifting sand dune area adjacent to the sea. It occurs in a mosaic distribution pattern with communities 3, 4 and 5. The community is situated at an altitude of $1-20 \mathrm{~m}$, on steep gradients. This vegetation is restricted to the drier northerly mid-slopes of coastal dunes, facing inland (Fig. 2). The soil is of the Namib form and no rocks are present.

The vegetation consists of low prostrate shrubs, with a few short, high and tall shrubs also present. The low shrub stratum is prominent with an average cover of $51 \%$ (Table 2).

The low shrub Solanum africanum (Species Group L, Table 1) is not only diagnostic but also dominant in the community. The shrub Chrysanthemoides monilifera (Species Group Q) is also locally prominent.

The community contains an average of only four species per relevé.

3. Chrysanthemoides monilifera - Ehrharta villosa var. maxima Low to High Closed Dune Shrub Community

The community is found in the sparsely vegetated shifting dune area adjacent to the sea, in a mosaic distribution pattern with communities 2, 4 and 5. It is also present in a mosaic distribution pattern with communities 2 and 4 in the more densely vegetated sand dune area at the seashore and directly behind to the shifting sand dune area (Fig. 2). No rocks are present in this habitat and the soil is of the Namib form.

The vegetation consists of short and low shrubs, with some short, high and tall shrubs as well as some low forbs, and low and short grasses present (Table 2).

The shrub Stoebe cinerea and the grass Ehrharta villosa var. maxima (Species Group M, Table 1), are diagnostic for the community and Chrysanthemoides monilifera (Species Group Q) is the dominant species. The shrubs Solanum africanum (Species Group L), Stoebe cinerea (Species Group M), Morella cordifolia (Species Group O), Passerina rigida (Species Group P) and Metalasia muricata (Species Group Q) are locally prominent species.

The community has an average of ten species per relevé.

3.1 Chrysanthemoides monilifera - Rhus crenata Short to High Dune Shrub Sub-community

The sub-community is found on north-facing coastal dune slopes with steep gradients of $26^{\circ}-45^{\circ}$, sheltered from the south-eastern wind carrying salt spray. No rocks are found here (Fig. 2).

The vegetation consists of short to high shrubs, with a few tall shrubs. Low forbs, low restios, low sedges, and low, short and high grasses have low cover values.

The shrub Rhus crenata (Species Group N, Table 1) is the only diagnostic species. Passerina rigida (Species Group P), Chrysanthemoides monilifera and Metalasia muricata (Species Group Q) are dominant whereas the shrubs Solanum africanum (Species Group L), Stoebe cinerea (Species Group M), Morella cordifolia (Species Group O), and the grass Ehrharta villosa var. maxima (Species Group $\mathrm{M}$ ) are also locally prominent in the sub-community.

The sub-community contains an average of 12 species per relevé.

\subsection{Chrysanthemoides monilifera - Morella cordifolia Low to Short Closed Dune Shrub Sub-community}

The steep $\left(16->45^{\circ}\right)$ southerly-facing midslopes dunes where this sub-community occurs are larger, more exposed areas than 
those where sub-community 3.1 occurs. The vegetation is exposed to sea mist (Fig. 2). The leaf structure and orientation of the most dominant plant species, Morella cordifolia, enhances the ability of the plant to catch moisture from sea fog.

The vegetation consists of low to short shrubs, with some high and tall shrubs, as well as some low forbs, low restios, low sedges, and low, short and high grass.

The shrubs Morella cordifolia, Lessertia frutescens (Species Group O, Table 1), are dominant diagnostic species, and Chrysanthemoides monilifera (Species Group Q is also dominant. The shrubs Stoebe cinerea (Species Group M), Passerina rigida (Species Group P) and Metalasia muricata (Species Group Q), and the grass Ehrharta villosa var. maxima (Species Group M) are locally prominent.

The sub-community contains an average of 11 species per relevé.

4. Ehrharta villosa var. maxima Low to Short Closed Dune Grassland Community

The community is found on steep, exposed southern slopes of sparsely vegetated stable sand dunes, or the more mobile shifting sand dunes adjacent to the sea. (Fig. 2). No rocks are present in the Namib soil form.

The community is found in a mosaic distribution pattern with communities 2, 3 and 5 and also in a mosaic distribution pattern with community 6 in the coastal beach area, adjacent to the sea.

The vegetation is low to short dune grassland, with a few high grasses. (Table 2).

The grass Ehrharta villosa var. maxima (Species Group M, Table ) is the sole diagnostic and dominant species in the community. No other species occur here.

5. Ammophila arenaria Low to Short Closed Dune Grassland Community

The community occurs on the steep, dry and warm north-facing slopes of sparsely vegetated shifting sand dunes, in a mosaic dis- tribution pattern with communities 2, 3 and 4 (Fig. 2).

The vegetation is low to short dune grassland. The shrub stratum has an average height of $1 \mathrm{~m}$ and an average canopy cover of $10 \%$ and the grass stratum has an average height of $0.7 \mathrm{~m}$ and an average canopy cover of $44 \%$ (Table 2 ).

The exotic grass Ammophila arenaria (Species Group R, Table 1) is the diagnostic and dominant species in the community. Other species present are Lessertia frutescens and Senecio arenarius.

The community contains an average of only three species per relevé.

6. Arctotheca populifolia - Thinopyrum distichum Short to Low Open Beach Community

The community is situated on the beach and south-facing slopes of low fore dunes, directly adjacent to the sea, and also on gravel plains behind the low fore dunes (Fig. 2).

There are no rocks on the beach and dunes and 30-50\% rock cover on the gravel plain. The rocks on the gravel plain are mostly sandstone and quartzite roll-stones, deposited by the sea while the lea level was higher.

The vegetation consists of short to low open beach grassveld with low forbs (Table 2).

The forb Arctotheca populifolia and the grass Thinopyrum distichum (Species Group $\mathrm{S}$, Table 2) are diagnostic and are the only species found in this community.

The community contains an average of only two species per relevé.

\section{Discussion}

The use of TWINSPAN and the application of Braun-Blanquet procedures for refinement, were successful to classify the plant communities of this vegetation type. Six plant communities, with eight sub-communities and four variants, were identified. The plant communities could all be related to specific environmental conditions and are therefore 
floristically and ecologically distinguishable and interpretable.

The thicket community (community 1) forms part of the Dune Thicket vegetation type of the Thicket Biome (Low \& Rebelo 1998), whereas the other communities form part of the Fynbos Biome (Low \& Rebelo). The thicket was mostly found in a mosaic with the vegetation of the inland plains and hills (Zietsman \& Bredenkamp in press). The thicket community does not only differ from the Fynbos communities concerning species composition and structure, but also in conservation importance. According to Low \& Rebelo (1998) 14.49 \% of Dune Thicket is currently being conserved, as opposed to the $1.42 \%$ of South and Southwest Coast Renosterveld and the $13.84 \%$ of Limestone Fynbos (Low \& Rebelo 1998).

According to Cowling \& Richardson (1995), if fire could be excluded from Fynbos for a century or two, many of the landscapes would become densely populated with just a few species of thicket shrubs and trees. Inland thicket development is therefore a feature of vegetation that has not been subjected to fire for some time. The species richness of this thicket is very low compared to those of Fynbos and Renosterveld (Zietsman \& Bredenkamp in press) and the true thicket species like Rhus glauca and Euclea racemosa, are neither rare nor endemic. The Limestone communities and the Renosterveld community, within which the thicket patches are found, have high conservation priority. Renosterveld has a very high conservation priority due to the small portion left, mainly because of agricultural land clearing (Low \& Rebelo 1998; Zietsman \& Bredenkamp in press). Limestone Fynbos is one of the most threatened vegetation types in the Cape Floristic Region (Hilton-Taylor \& Le Roux 1989). There are 110 plant species endemic to limestone outcrops. Limestone Fynbos also contains many species that are classified as rare (Heydenrych 1994). Thicket forming should be seen as a threat to the natural Fynbos and Renosterveld vegetation, and should not be encouraged above the conservation of the other Fynbos and Renosterveld vegetation.
The presence of sub-community 1.5 (Acacia cyclops - Euclea racemosa High toTall Closed Thicket Sub-community) is a reason for concern. Acacia cyclops occurs scattered in various communities, fairly well distributed throughout Andrew's Field and TsabaTsaba Nature Reserve, but the larger stands found locally represent sub-community 1.5. All areas containing Acacia cyclops, should be managed by implementing regular prescribed burning, and alien-invasive plant control, ideally by means of the cut-and-burn method (Cowling 1992), but the current woodcutting method (promoting job provision), can also be followed. The conservation of Limestone and Renosterveld vegetation should be treated as a high priority.

Fire should be kept out of the dune area, because, according to Tinley (1985) fire might cause an increase in dune instability. Fire should also be kept out of areas that are heavily infested with the Cape dune molerat. According to Tinley (1985) fire would lead to an undesired increase in burrowing by Cape dune molerats to obtain sufficient food (roots). Therefore, as extensive dune molerat burrowing is already a problem in some areas in the reserve, fire should be kept out of those areas. Other areas should be burned using a 15-year block-burn cycle to avoid the possible substitution of Limestone and Renosterveld vegetation by dense thickets.

A single Red Data species (Solanum africanum) is found quite abundantly in the dune area (communities 2 and 3). The presence of Limestone endemic species in the dune area can be explained by the fact that both the dune sands and the limestone soil are alkaline. The shifting sand dune area should be protected from disturbances, like trampling and vehicle tracks. Protection from disturbances should also provide sufficient protection to the Red Data and Limestone endemic species.

Community 9 is dominated by Ammophila arenaria, an exotic grass which is an European weed, commonly found on coastal dunes (Goldblatt \& Manning 2000).

Although community 6 contains no rare or endemic species, the vegetation unit should 
be protected due to its uniqueness, and due to the fact that this gravel-plain is the breeding site of the rare Damara Tern Sterna balaenarum (Jeffery 1996).

Andrew's Field and Tsaba-Tsaba Nature Reserve is an area of great conservation significance. This area comprises an important part of the natural heritage found at the southern tip of Africa, and should be protected and conserved for future generations. The resulting classification provides a useful tool, not only for the management of the plant communities of Andrew's Field and Tsaba-Tsaba Nature Reserve, but also for similar vegetation areas, found in the surrounding region.

\section{Acknowledgements}

Mrs. F. Siebert is thanked for her assistance during data processing.

\section{References}

Behr, C.M. \& G.J. BredenKAMP. 1988. A phytosociological classification of thevegetation of the Witwatersrand National Botanic Garden. South African Journal of Botany 54(6): 525-533.

BREDENKAMP, G.J. \& L.R. BROWN. 2001. Vegetation - a reliable ecological basis for environmental planning. Urban Greenfile Nov-Dec 2001: 38-39.

Cowling, R.M. (ed.). 1992. The ecology of Fynbos: nutrients, fire and diversity. Cape Town: Oxford University Press.

Cowling, R.M. \& D. Richardson. 1995. Fynbos: South Africa's Unique floral kingdom. Cape Town: Fernwood Press.

EDWARDS, D. 1972. Botanical survey and agriculture. Proceedings of the Grassland Society of Southern Africa 7: 15-17.

EDWARDS, D. 1983. A broad-scale structural classification of vegetation for practical purposes. Bothalia 14: 705-712.

GoldBlatt, P. \& J. Manning. 2000. Cape plants - a conspectus of the Cape Flora of South Africa. Pretoria: National Botanical Institute of South Africa.

Heydenrych, B.J. 1994. Limestone Fynbos Unique but Threatened. An investigation into the conservation status of Limestone Fynbos in the southern Cape. Kirstenbosch: Botanical Society of South Africa. (Flora Conservation Committee report no. 94/1.)

HILL, M.O. 1979. TWINSPAN: A Fortran program for arranging multivariate data in an ordered two-way table by classification of the individuals and attributes. New York: Cornell University.

Hilton-TAYlor, C. \& A. LE Roux. 1989. Conservation status of the Fynbos and Karoo biomes. Pp. 202-233. In: Huntley, B.J. (ed.). Biotic diversity in Southern Africa: concepts and conservation. Cape Town: Oxford University Press.

Heydorn, A.E.F. \& K.L. TinLey. 1980. Estuaries of the Cape, part 1: Synopsis of the Cape coast natural features, dynamics \& utilization. Stellenbosch: Council for Scientific \& Industrial Research, National Research Institute for Oceanology. (Council for Scientific \& Industrial Research research report; no. 380.)

JEFFERY, D. 1996. An abbreviation of the botanical sensitivity analysis report for portion 7 and remainder portion 8 of the farm Zoetendalsvlei no. 280 of July 1995. Environmental consulting and facilitation services, Klapmuts.

Low, A.B. \& A.G. Rebelo. 1998. Vegetation of South Africa, Lesotho and Swaziland: A companion to the vegetation map of South Africa, Lesotho and Swaziland. Pretoria: Department of Environmental Affairs \& Tourism.

MACVICAR, C.N. 1991. Grondklassifikasie 'n taksonomiese sisteem vir Suid-Africa. Pretoria: Departement van Landbou-Ontwikkeling,

Malan, J.A., J.H.A. Viljoen, H.P. Siegfried \& H. DE V. WICKENS. 1994. Die geologie van die gebied Riversdale. Pretoria: Staatsdrukker.

Mustard, P., R. Cowling \& J. Albertyn. 1997. Southern Overberg: South African wildflower guide 8. Cape Town: National Book Printers.

SCHEEPERS, J.C. 1983. Vegetation studies in South Africa. Bothalia 14: 683-690.

Strydom, S. 1992. A classification of Southern Cape coastal dunes and the associated vegetation. MSc: thesis, University of Port Elizabeth, Port Elizabeth.

Tinley, K.L. 1985. Coastal dunes of South Africa. Pretoria: Council for Scientific and Industrial Research, National Scientific Programmes Unit. (South African National Scientific Programmes report; no. 109.)

WERGER, M.J.A. 1974. On concepts and techniques applied in the Zürich-Montpellier method of vegetation survey. Bothalia 11: 309-323.

Zietsman, M.M. \& G.J. BredenKamp (in press). Threatened Limestone Fynbos plant communities of Andrew's Field and Tsaba-Tsaba Nature Reserve. Bothalia. 